\title{
Analisis Potensi Likuifaksi Di Wilayah Cekungan Bandung dengan Menggunakan Metode Uji Penetrasi Konus
}

\author{
Iswanti Widiya Ambarwati ${ }^{1}$, Selly Feranie ${ }^{2}$, Adrin Tohari ${ }^{3 *}$ \\ ${ }^{1}$ Mahasiswa S-1 Jurusan Fisika, FPMIPA, Universitas Pendidikan Indonesia, Bandung 40154 \\ ${ }^{2}$ Prodi Fisika, FPMIPA, Universitas Pendidikan Indonesia, Bandung 40154 \\ ${ }^{3}$ Pusat Penelitian Geoteknologi-LIPI, Komplek LIPI, Jl. Sangkuriang, Bandung 40135
}

\begin{abstract}
ABSTRAK Secara geologi, wilayah Cekungan Bandung tersusun atas lapisan endapan danau purba yang rentan terhadap risiko gempa bumi. Dengan demikian, pengetahuan mengenai potensi likuifaksi di wilayah ini sangat diperlukan untuk mengurangi risiko gempa bumi. Makalah ini menyajikan hasil evaluasi potensi likuifaksi dan penurunan tanah akibat likuifaksi dengan menggunakan metode uji penetrasi konus (CPT) dengan mempertimbangkan gempa bumi dari zona Sesar Lembang (Mw 6,5) dan zona subduksi selatan Jawa (Mw 7,0). Berdasarkan skenario gempa bumi tersebut, penurunan tanah total sangat bervariasi disebabkan oleh perbedaan ketebalan lapisan pasir lanauan di setiap lokasi. Mempertimbangkan perbedaan percepatan tanah puncak, penurunan tanah total akibat gempa bumi dari zona Sesar Lembang akan lebih tinggi dibandingkan dengan penurunan tanah total akibat gempa bumi megathrust di selatan Jawa.
\end{abstract}

Kata kunci: Cekungan Bandung, gempa bumi, likuifaksi, uji penetrasi konus, percepatan tanah puncak, rasio tegangan siklik, rasio hambatan siklik.

Naskah masuk : 27 Maret 2019

Naskah direvisi : 8 Desemeber 2019

Naskah diterima : 16 Maret 2020

*Penulis korespondensi.

Email : adrin.tohari@gmail.com
ABSTRACT liquefaction potential analysis in bandung basin area using cone penetration test method Bandung basin region is geologically composed of ancient lake sediments that are susceptible to earthquake risk. Therefore, knowledge of the potential for liquefaction in this region is needed to reduce the risk of earthquakes. This paper presents the results of the evaluation of the potential for liquefaction and ground settlement due to liquefaction using the CPT method by considering earthquakes from the Lembang Fault zone (Mw 6.5) and the southern Java subduction zone (Mw 7.0). Based on the earthquake scenario, the CPT locations will have a different liquefaction potential and total ground settlement due to differences in the thickness of the silty sand layer at each location. In an account of the difference in peak ground acceleration, the total ground settlement due to earthquakes from the Lembang Fault zone will be higher than that caused by the megathrust in southern Java.

Keywords: Bandung basin, earthquake, liquefaction, cone penetration test, peak ground acceleration, cyclic stress ratio, cyclic resistance ratio.

\section{PENDAHULUAN}

Gempa bumi merupakan salah satu bencana alam yang dapat menyebabkan kerusakan pada struktur tanah. Gempa bumi salah satunya dapat di akibatkan oleh adanya aktivitas teknonik yang terdapat di sepanjang batas lempeng tektonik yang mengakibatkan adanya gelombang yang merambat pada permukaan bumi. Indonesia merupakan salah satu negara yang memiliki tingkat kejadian gempa bumi besar yang cukup tinggi. Hal ini dipengaruhi oleh letak Indonesia yang berada pada pertemuan lempeng IndoAustralia, lempeng Pasifik, lempeng Eurasia dan lempeng Filipina. 
Salah satu bahaya ikutan gempa bumi adalah likuifaksi yang terjadi akibat adanya perubahan struktur tanah yang terjadi akibat goncangan gempa bumi. Likuifaksi biasanya terjadi pada daerah-daerah yang terbentuk oleh endapan aluvial dan endapan lepas. Menurut Towhata (2008), likuifaksi dapat terjadi pada tanah yang berpasir lepas dan jenuh air, seiring dengan adanya kenaikan tekanan air pori saat terjadinya gempa bumi maka tekanan efektifnya akan berkurang seiring waktu.

Kedudukan muka air tanah akan mengontrol potensi terjadinya likuifaksi. Likuifaksi umumnya terjadi pada daerah yang memiliki muka air tanah dangkal. Menurut Youd et al. (1979), potensi likuifaksi dapat terjadi pada wilayah yang memiliki kedalaman muka air tanah hingga 15,2 $\mathrm{m}$ dengan tingkat kerentanan terhadap likuifaksi yang bervariasi. Kerentanan terhadap likuifaksi akan menurun dengan bertambahnya kedalaman muka air tanah.

Selama kurun waktu 20 tahun, beberapa kejadian likuifaksi telah terjadi pada wilayah Indonesia diantaranya likuifaksi yang terjadi akibat gempa bumi di Aceh pada tahun 2004 (Mw 9,1), gempa bumi yang terjadi di Nias pada tahun 2005 (Mw 8,7). Selain itu, likuifaksi juga terjadi akibat gempa bumi di wilayah Bantul pada tahun 2006 (Mw 6,3), pada gempa bumi di Bengkulu tahun 2007 (Mw 8,4), pada gempa bumi kota Padang tahun 2009 (Mw 7,6), dan likuifaksi yang terjadi di Palu akibat gempa bumi pada tahun 2018 (Mw 7,4 ) yang menyebabkan korban jiwa dan kerugian ekonomi yang besar.

Analisis potensi likuifaksi dapat dilakukan dengan menggunakan tiga metode pengujian lapangan, yaitu uji penetrasi standar (SPT), uji penetrasi konus $(C P T)$ dan pengukuran kecepatan geser $\left(V_{s}\right)$. Dari tiga metode ini, metode $C P T$ mempunyai kelebihan utama yaitu hasil uji $C P T$ lebih konsisten mendeteksi variasi jenis lapisan tanah dengan kontrol kualitas data yang lebih baik dibandingkan metode pengujian lapangan lainnya (Youd et al., 2001). Dengan demikian, metode CPT dapat memberikan informasi kedalaman dan ketebalan lapisan tanah yang mempunyai potensi likuifaksi lebih akurat dibandingkan dengan jenis metode lainnya. Tohari et al. (2011; 2015) menggunakan metode uji penetrasi konus untuk memprediksi kerentanan likuifaksi di wilayah Kota Padang dan Kota Banda Aceh. Hasil analisis potensi likuifaksi di Kota Padang memperlihatkan kesesuaian dengan fenomena likuifaksi yang terjadi saat gempa bumi tahun 2009.

Wilayah Cekungan Bandung merupakan salah satu wilayah yang memiliki tingkat kerentanan yang tinggi terhadap gempa bumi. Salah satu sumber gempa bumi di daratan yang berpotensi memberikan dampak langsung ke wilayah Cekungan Bandung adalah Sesar Lembang, yang mempunyai panjang $29 \mathrm{~km}$, sehingga dapat menghasilkan gempa bumi berskala Mw berkisar antara 6,5 dan 7,0 dengan waktu pengulangan 170 - 670 tahun (Daryono et al., 2019). Menurut Tjia (1968) dan Afnimar et al. (2015), Sesar Lembang didominasi oleh pergerakan mendatar mengiri (left-lateral), sedangkan hasil studi lainnya (Hidayat et al., 2008; Van Bemmelen, 1949) mengindikasikan bahwa Sesar Lembang merupakan sesar normal. Berdasarkan penelitian Sulaeman dan Hidayati (2011), gempa bumi (M 3 ,4) yang terjadi pada bulan Juli dan Agustus 2011 di daerah Cisarua, Lembang, Kabupaten Bandung Barat disebabkan oleh pergerakan Sesar Lembang. Selain itu, sumber gempa bumi di zona subduksi selatan Jawa juga dapat memberikan dampak di wilayah ini. Gempa bumi subduksi (Mw 7,0) yang terjadi pada tanggal 2 September 2009 juga dirasakan di wilayah Kabupaten Bandung dan Kota Bandung (USGS, 2009).

Secara geologi satuan batuan termuda yang mengisi cekungan Bandung merupakan batuan hasil endapan danau yang berukuran lempung, lanau, pasir, dan kerikil yang bersifat tufan yang belum terpadatkan (Bronto dan Hartono, 2006). Menurut Hutasoit (2009), lapisan endapan danau ini mempunyai ketebalan mencapai 150-200 m. Berdasarkan stratigrafi yang disederhanakan yang berasal dari data pemboran, Harnandi et al. (2000) menyimpulkan keberadaan akuifer dangkal pada kedalaman 0-35 $\mathrm{m}$ di bawah permukaan tanah di daerah Cekungan Bandung. Selain itu, berdasarkan data kedudukan muka air tanah dan peta sebaran muka air tanah, Hutasoit (2009) berpendapat bahwa terdapat beberapa daerah di wilayah Cekungan Bandung yang memiliki kedudukan muka air tanah yang dangkal $(<10 \mathrm{~m})$.

Mempertimbangkan faktor kegempaan, geologi, dan hidrologi wilayah Cekungan Bandung, maka perlu dilakukan studi potensi likuifaksi sebagai dasar untuk melakukan upaya pengurangan risiko gempa bumi di wilayah ini. Makalah ini 


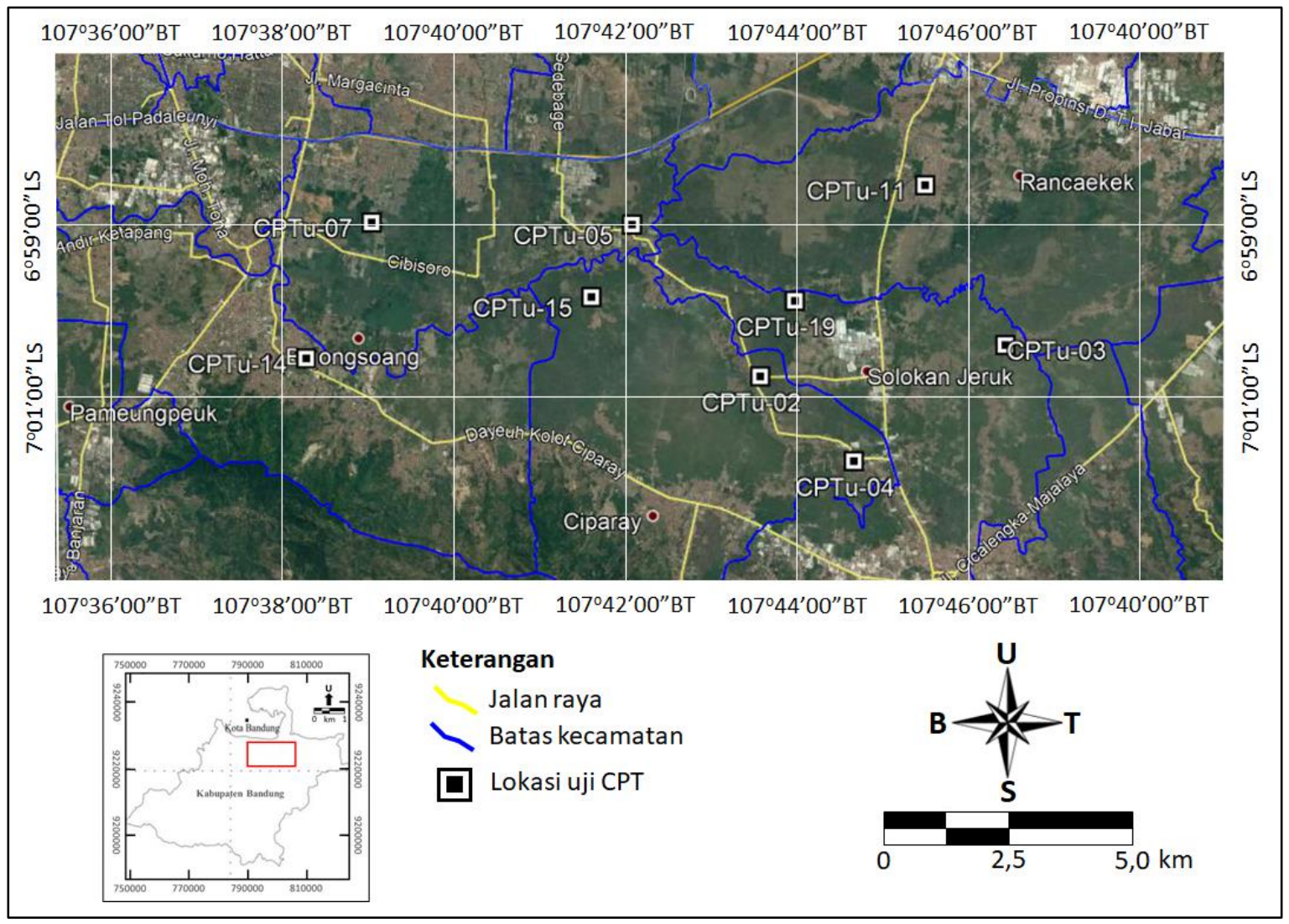

Gambar 1. Peta lokasi pengambilan data CPT

menyajikan hasil analisis potensi likuifaksi pada wilayah Cekungan Bandung berdasarkan data Cone Penetration Test $(C P T)$, dengan sasaran yaitu untuk mengetahui kedalaman lapisan tanah yang berpotensi likuifaksi dan menentukan besar penurunan tanah akibat likuifaksi. Tabel 1 dan Gambar 1 menyajikan lokasi penelitian yang berada di wilayah Kabupaten Bandung. Analisis potensi likuifaksi akan mempertimbangkan dua skenario sumber gempabumi yaitu Sesar Lembang (Mw 6,5) dan megathrust (Mw 7,0) dari zona subduksi selatan Jawa.

\section{TATANAN GEOLOGI CEKUNGAN BANDUNG}

Cekungan Bandung merupakan cekungan yang sebagian besar wilayahnya dikelilingi oleh dataran tinggi vulkanik. Cekungan Bandung memiliki luas sekitar $2.300 \mathrm{~km}^{2}$ dan mencakup tiga unit administrasi, yang terdiri dari Kota Bandung, Kabupaten Bandung dan bagian dari Kabupaten Sumedang. Bagian tengah Cekungan Bandung, sebagian besar ditempati oleh daerah perkotaan dan industri. Pada bagian tengah, cekungan
Bandung dikelilingi oleh dataran tinggi vulkanik Akhir Tersier dan Kuarter yang memiliki ketinggian sekitar $665 \mathrm{~m}$ hingga $2400 \mathrm{~m}$ (Dam et al., 1996).

Secara geologi, batuan gunungapi berumur Tersier dan batugamping yang termasuk ke dalam Formasi Rajamandala (Sudjatmiko, 2003) merupakan batuan dasar yang dijumpai pada bagian barat Cekungan Bandung. Sebagai batuan dasar dari Cekungan Bandung pada bagian tengah adalah Formasi Cikapundung yang terdiri atas konglomerat dan breksi kompak, tuf, dan lava andesit berumur Pleistosen Awal. Lapisan batuan di atas Formasi Cikapundung adalah Formasi Cibeureum dan Kosambi. Menurut Koesoemadinata dan Hartono (1981), Formasi Cibeureum berbentuk kipas yang bersumber dari Gunung Tangkubanparahu. Formasi ini terutama terdiri atas perulangan breksi dan tuf dengan tingkat konsolidasi rendah serta beberapa sisipan lava basal, dengan umur Plistosen Akhir Holosen. Breksi dalam formasi ini adalah breksi vulkanik yang disusun oleh fragmen-fragmen skoria batuan beku andesit basal dan batu apung. 
Tabel 1. Lokasi pengambilan data CPT

\begin{tabular}{cccl}
\hline \multirow{2}{*}{ Kode lokasi } & Koordinat (UTM) & & \multicolumn{1}{c}{ Lokasi } \\
& $\mathrm{mE}$ & $\mathrm{mS}$ & \\
\hline CPTu-02 & 801139 & 9224140 & Desa Rancakesumba, Kec. Solokan Jeruk \\
CPTu-04 & 803115 & 9222325 & Desa Rancakesumba, Kec. Solokan Jeruk \\
CPTu-05 & 798441 & 9227383 & Desa Tegalluar, Kec. Bojongsoang \\
CPTu-07 & 792888 & 9227490 & Desa Cipalago, Kec. Bojongsoang \\
CPTu-03 & 806375 & 9224745 & Desa Padamukti, Kec. Solokan Jeruk \\
CPTu-11 & 804701 & 9228146 & Kelurahan Rancaekek Kusuma, Kec. Rancaekek \\
CPTu-14 & 791460 & 9224628 & Desa Baleendah, Kec. Baleendah \\
CPTu-15 & 797557 & 9225859 & Desa Sumbersari, Kec. Ciparay \\
CPTu-19 & 801895 & 9225730 & Desa Bojongemas, Kec. Solokan Jeruk \\
\hline
\end{tabular}

Formasi Kosambi diusulkan oleh Koesoemadinata dan Hartono (1981) untuk menggantikan nama Endapan Danau yang digunakan oleh Silitonga (1973). Berdasarkan litologinya, formasi ini terdiri atas endapan lempung, lanau, dan pasir yang belum kompak dengan umur Holosen.

Cekungan air tanah Bandung memiliki luas sekitar $1.730 \mathrm{~km}^{2}$ yang dibentuk oleh empat sistem akuifer yang mengandung air tanah potensial yang terdiri dari Formasi Cibeureum, Formasi Kosambi, Formasi Cikapundung dan Formasi Gunungapi muda. Berdasarkan letak dan kondisinya, akuifer ini dapat dibagi menjadi tiga kelompok akuifer yang terdiri dari akuifer dangkal pada kedalaman 0-40 m, akuifer tengah pada kedalaman 40-150 m dan akuifer dalam yang teletak pada kedalaman > 150 m (Harnandi et al., 2000)

\section{METODE}

Cone Penetration Test (CPT) atau uji penetrasi konus digunakan untuk mendapatkan nilai tahanan konus $\left(q_{c}\right)$ dan hambatan selimut $\left(f_{s}\right)$ setiap jenis lapisan tanah. Nilai tahanan konus $\left(q_{c}\right)$ adalah gaya penetrasi per satuan luas penampang konus. Besarnya gaya ini seringkali menunjukkan identifikasi dari jenis tanah dan konsistensinya. Pada tanah pasiran, tahanan ujung jauh lebih besar daripada tanah butiran halus. Sedangkan hambatan selimut $\left(f_{s}\right)$ adalah gaya yang diperlukan untuk menekan masuk selubung per satuan luas selubung geser.

Uji penetrasi konus ini dilakukan hingga mencapai lapisan tanah padat dengan nilai $q_{c}$ mencapai 15 $\mathrm{MPa}$ Korelasi nilai $q_{c}$ dan $f_{s}$ yang sudah dinormalisasi akan memberikan indeks perilaku tanah, $I_{c}$ (Robertson, 1990), yang dinyatakan dengan persamaan dibawah ini:

$I_{c}=\left[(3,47-\log Q)^{2}+(1,22+\log F)^{2}\right]^{0,5}$

, dimana $Q$ adalah tahanan konus ternormalisasi, dan $F$ adalah rasio friksi yang diperoleh melalui persamaan berikut (Robertson dan Wride, 1998):

$Q=\left[\left(q_{c}-\sigma_{v o}\right) / P_{a}\right] \times\left[P_{a} / \sigma_{v o}^{\prime}\right]^{n}$

$F=\left(f_{s} /\left(q_{c}-\sigma_{v o}\right)\right) \times 100$

, dimana $q_{c}$ adalah tahanan konus $(\mathrm{kPa}), f_{s}$ adalah hambatan selimut $(\mathrm{kPa}), \sigma_{v o}^{\prime}$ adalah tegangan vertikal efektif $(\mathrm{kPa}), \sigma_{v o}$ adalah tegangan vertikal total $(\mathrm{kPa})$ dan $P_{a}$ adalah tekanan atmosfir (1 atm).

\section{Percepatan Tanah Puncak}

Perhitungan percepatan tanah puncak (PGA) mempertimbangan dua buah sumber gempa bumi, yaitu Sesar Lembang dengan kekuatan gempa bumi, Mw sebesar 6,5 (Daryono et al., 2019) dan sumber gempa bumi megathrust dengan $\mathrm{Mw}$ sebesar 7,0 yang berasal dari zona subduksi selatan Jawa (USGS, 2009). Gambar 2 menyajikan lokasi episenter sumber gempa bumi pada zona Sesar Lembang dan megathrust di selatan Jawa yang digunakan dalam perhitungan $P G A$. Perhitungan $P G A$ untuk sumber gempa bumi dari zona Sesar Lembang dengan mekanisme pergerakan sesar yang tidak ditentukan (not specified) menggunakan persamaan atenuasi Boore et al. (1997) sebagai berikut:

$$
\begin{aligned}
& \ln Y=b_{1}+b_{2}(M-6)+b_{3}(M-6)^{2}+ \\
& b_{5} \ln r+\quad b_{v} \ln \left(V_{s 30} / V_{A}\right)
\end{aligned}
$$

dimana $Y$ adalah percepatan horizontal puncak dalam satuan $g, M$ adalah moment magnitude 
gempa, $\quad r=\sqrt{d^{2}+h^{2}}, d$ merupakan jarak episentrum (dalam satuan $\mathrm{km}$ ), $V_{S 30}$ adalah kecepatan gelombang geser rata-rata hingga kedalaman $30 \mathrm{~m}$ (dalam satuan m/detik), dan $b_{l}$, $b_{2}, b_{3}, b_{5}, b_{v}, h$, dan $V_{A}$ merupakan koefisien dimana $b_{1}=-0,242, b_{2}=0,527, b_{3}=0, b_{5}=-0,778, b_{v}=-$ $0,371, h=5,57, \mathrm{~V}_{\mathrm{A}}=1396$ (Boore et al., 1997).

Sedangkan perhitungan $P G A$ untuk sumber gempa bumi megathrust dari zona subduksi selatan Jawa menggunakan persamaan Youngs et al. (1997) sebagai berikut:

$$
\begin{aligned}
\ln (P G A)= & -0,6687+1,438 M-2,329 \ln \left(r_{\text {rup }}+\right. \\
& 1.097 e^{0,617 M}+0,00648 H+ \\
& \left.0,3846 Z_{t}\right)
\end{aligned}
$$

dimana $M$ adalah magnitudo momen gempa, $r_{r u p}$ adalah jarak horizontal dari sumber gempa ke lokasi uji $C P T(\mathrm{~km}), d$ adalah jarak episentrum $(\mathrm{km})$ dan $h$ adalah kedalaman pusat gempa $(\mathrm{km})$, $H$ adalah kedalaman pusat gempa $(\mathrm{km}) ; Z_{t}$ adalah jenis dari sumber gempa ( 0 untuk megathrust dan 1 untuk benioff).

\section{Evaluasi Potensi Likuifaksi}

Berdasarkan data Cone Penetration Test (CPT), evaluasi potensi likuifaksi yang dilakukan yaitu dengan menentukan cyclic resistance ratio (CRR) dan cylic stress ratio (CSR). Persamaan Seed dan Idriss (1971) dapat digunakan untuk menghitung nilai $C S R$ sebagai berikut:

$\operatorname{CSR}=0,65\left(a_{\max } / g\right) \times\left(\sigma_{v o} / \sigma_{v o}^{\prime}\right) \times r_{d}$

dimana $C S R$ adalah rasio tegangan siklik, $a_{\max }$ adalah percepatan tanah puncak, $g$ adalah percepatan gravitasi $\left(9,81 \mathrm{~m} / \mathrm{det}^{2}\right), \sigma_{v \text { o }}$ adalah tegangan vertikal total $(\mathrm{kPa}), \sigma_{v_{0}}^{\prime}$ adalah tegangan vertikal efektif $(\mathrm{kPa})$, dan $r_{d}$ adalah koefisien pengurangan tegangan yang bergantung pada kedalaman $(z)$ dan dihitung dengan menggunakan persamaan dibawah ini (Liao dan Whitman, 1986b; Robertson dan Wride, 1997):

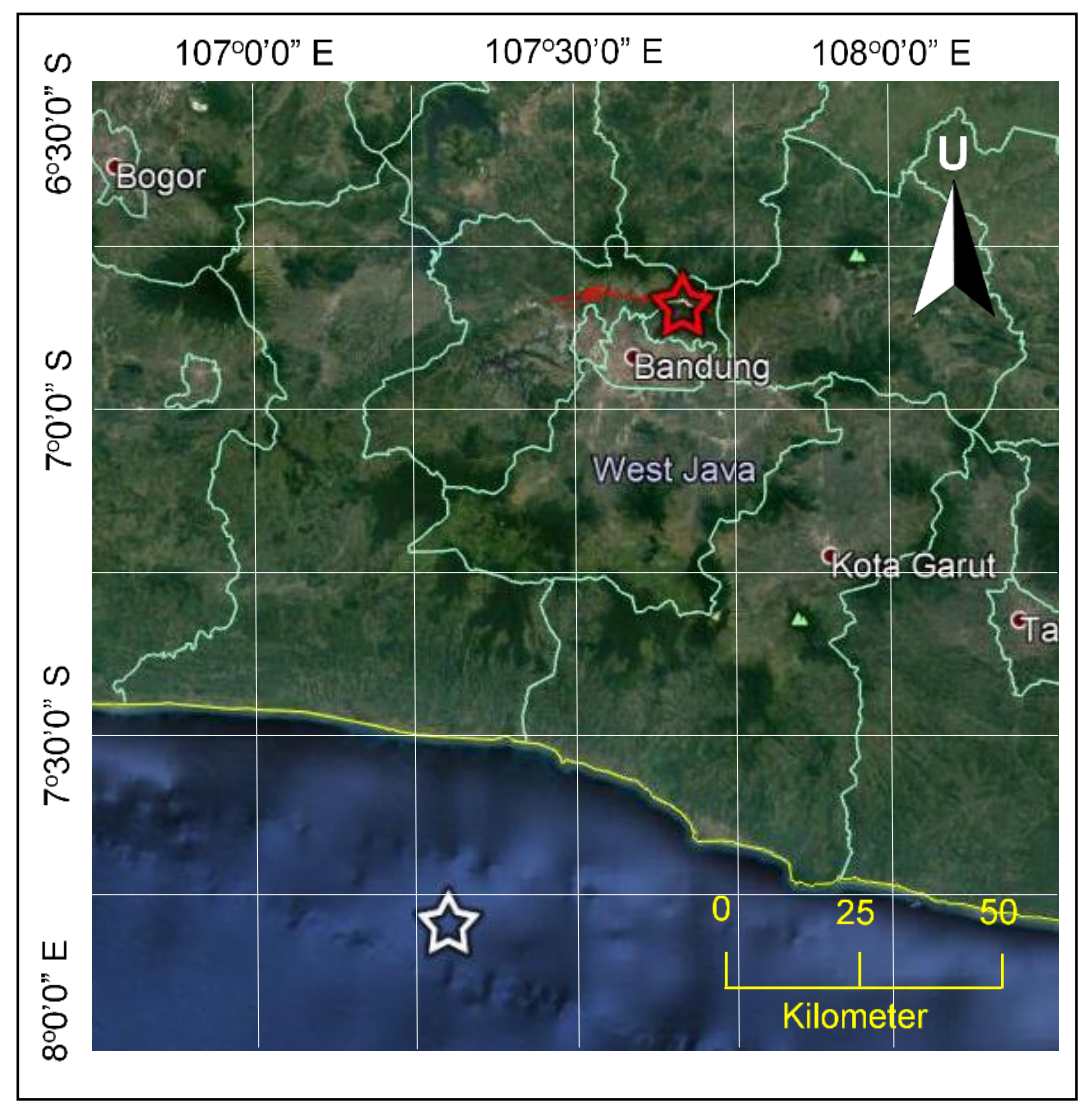

Gambar 2. Episenter sumber gempa bumi Sesar Lembang dengan Mw 6,5 (simbol bintang warna merah) dan megathrust di zona subduksi selatan Jawa dengan Mw 7,0 (simbol bintang warna putih). Sesar Lembang ditujukkan oleh garis warna merah. 


$$
\begin{aligned}
& r_{d}=1,0-0,00765 \times z \rightarrow z \leq 9,15 \mathrm{~m} \\
& r_{d}=1,174-0,0267 \times z \rightarrow 9,15 \mathrm{~m}<z<23 \mathrm{~m} \\
& r_{d}=0,744-0,0008 \times z \rightarrow 23 \mathrm{~m}<z<30 \mathrm{~m} \\
& r_{d}=0,5 \rightarrow z \geq 30
\end{aligned}
$$

Untuk mengetahui potensi likuifaksi, maka perlu dilakukan perhitungan nilai $C R R$ yang dapat dihasilkan dengan menggunakan prosedur Robertson dan Wride (1998) dibawah ini.

Jika nilai $\left(q_{c l N}\right)_{c s}<50$, maka

$C R R_{7,5}=0,833 \times\left(\left(q_{c 1 N}\right)_{c s} / 1000\right)+0,05$

Jika nilai $50<\left(q_{c l N}\right)_{c s}<160$, maka

$C R R_{7,5}=93 \times\left(\left(q_{c 1 N}\right)_{c s} / 1000\right)^{3}+0,08$

dimana $C R R_{7,5}$ adalah nilai hambatan siklik untuk magnitudo gempa $M w=7,5$ dan $\left(q_{c 1 N}\right)_{c s}$ adalah nilai tahanan konus terkoreksi yang dihitung dengan menggunakan persamaan (Robertson dan Wride, 1998) berikut:

$\left(q_{c 1 N}\right)_{c s}=K_{c} \times q_{c 1 N}$

dimana $q_{c 1 N}$ adalah tahanan konus ternormalisasi dan $K_{c}$ adalah faktor koreksi yang dihitung dengan menggunakan persamaan di bawah ini (Robertson dan Wride, 1998).

Jika $I_{c}<1,64$, maka

$K_{c}=1,0$

Jika $I_{c}>1,64$, maka

$K_{c}=-0,403 I_{c}^{4}+5,581 I_{c}^{3}-21,63 I_{c}^{2}+$

$33,75 I_{c}-\quad 17,88$

Hasil perhitungan nilai $C S R$ dan $C R R$ akan digunakan untuk menentukan faktor keamanan $(F K)$ terhadap likuifaksi dengan menggunakan persamaan berikut:

$F K=\left(C R R_{7,5} / C S R\right) \times M S F$

dimana $M S F$ adalah faktor kelipatan besaran gempa bumi, yang dapat ditentukan dengan menggunakan persamaan dibawah ini (Youd et al., 2001):

$M S F=10^{2,24} / M^{2,56}$ untuk $M<7,5$

Jika suatu wilayah berpotensi untuk mengalami likuifaksi maka dapat dipastikan wilayah tersebut berpotensi mengalami penurunan tanah. Besar penurunan tanah yang dapat terjadi di setiap lokasi CPT dapat diketahui dengan menggunakan persamaan Ishihara \& Yoshimine (1992) sebagai berikut:

$S=\sum_{i=1}^{j} \varepsilon_{v} \times \Delta z_{i}$

dimana $S$ adalah penurunan tanah total $(\mathrm{cm}), \varepsilon_{v}$ adalah regangan volumetrik pasca likuifaksi pada lapisan tanah ke-i $(\%)$ dan $\Delta z_{i}$ adalah ketebalan lapisan tanah ke-i (cm).

\section{HASIL DAN DISKUSI}

\section{Jenis Lapisan Tanah}

Gambar 3 hingga Gambar 5 menampilkan hasil karakteristik jenis tanah berdasarkan data uji penetrasi konus dengan menggunakan metode Robertson (1990). Berdasarkan hasil analisis data CPTu-02, lapisan tanah didominasi oleh lempung dengan sisipan pasir pada kedalaman 14 hingga 16 m (Gambar 3a). Pada lokasi CPTu-04, lapisan tanah didominasi oleh campuran lanau dan lempung pada kedalaman kurang dari $10 \mathrm{~m}$, sedangkan pada kedalaman lebih dari $10 \mathrm{~m}$ didominasi oleh lapisan tanah campuran pasir dan lanau dengan sisipan pasir pada kedalaman 10,05 hingga 10,65 m (Gambar 3b). Sementara itu, berdasarkan data CPTu-05 lapisan tanah tersusun oleh campuran lanau dan lempung dengan sisipan pasir pada kedalaman 9 hingga $10 \mathrm{~m}$ (Gambar 3c).

Lokasi uji CPTu-07 didominasi oleh lapisan lempung pada kedalaman 4 hingga $8 \mathrm{~m}$ dan lapisan tanah campuran lanau dan lempung pada kedalaman 0 hingga $4 \mathrm{~m}$ dan 9 hingga $10 \mathrm{~m}$ dengan sisipan campuran pasir dan lanau pada kedalaman 10,08 m (Gambar 4a). Sementara itu, lapisan lempung yang tebal, dengan sisipan campuran pasir dan lanau pada kedalaman 10,5 $11,5 \mathrm{~m}$, menyusun lapisan tanah di lokasi CPTu03 (Gambar 4b). Lapisan tanah pada lokasi CPTu11 tersusun oleh lapisan tanah campuran pasir dan lanau dan sisipan pasir pada kedalaman lebih dari $5 \mathrm{~m}$ (Gambar 4c).

Berdasarkan data CPTu-15, lapisan tanah didominasi oleh campuran lanau dan lempung dengan sisipan pasir pada kedalaman 11 hingga 14 $m$ dan 29 hingga 30,03 m (Gambar 5a). Sedangkan pada lokasi CPTu-14 dan CPTu-19, lapisan tanah didominasi oleh lempung dengan sisipan pasir pada kedalaman $5 \mathrm{~m}$ (Gambar 5b dan 5c). Keberadaan sisipan lapisan pasir akan mengontrol potensi likuifaksi pada kedalaman yang bervariasi. 

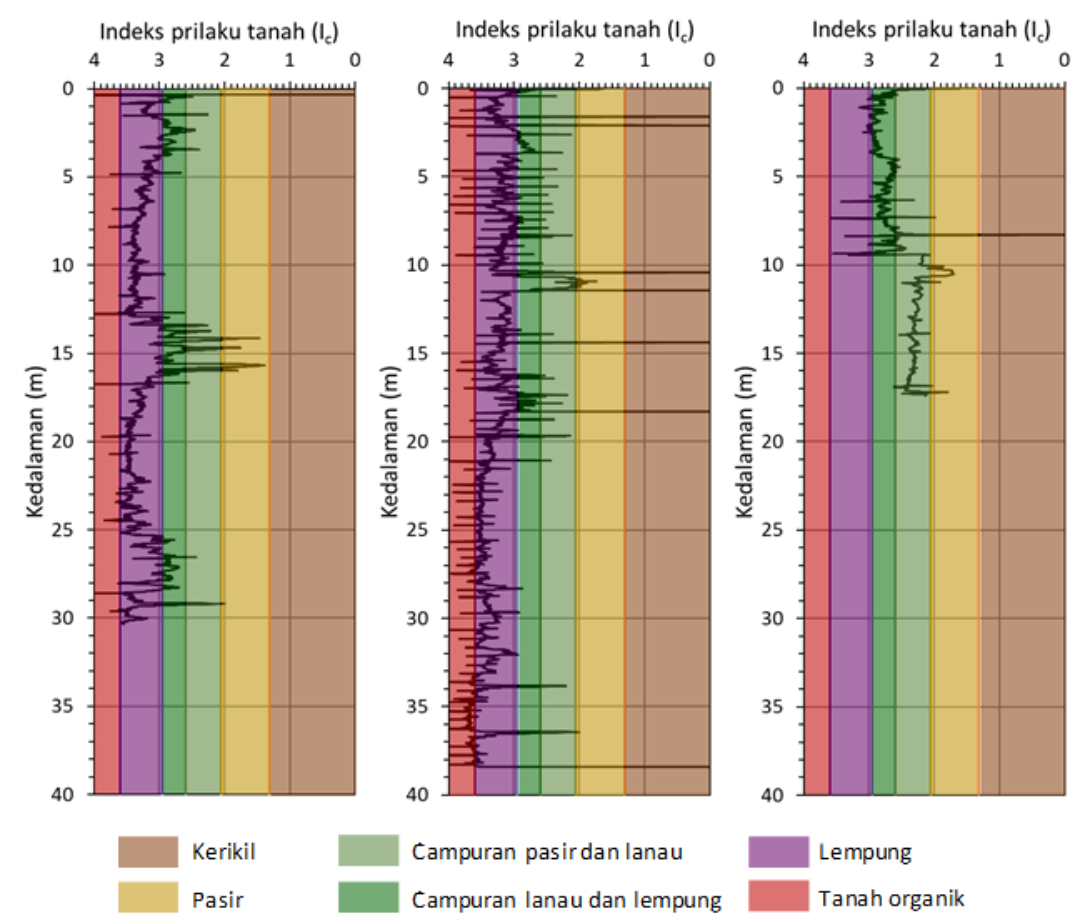

Gambar 3. Profil klasifikasi jenis lapisan tanah di lokasi CPTu-02 (kiri), CPTu-04 (tengah) dan CPTu-05 (kanan) berdasarkan nilai indeks perilaku tanah, Ic (Robertson, 1990).
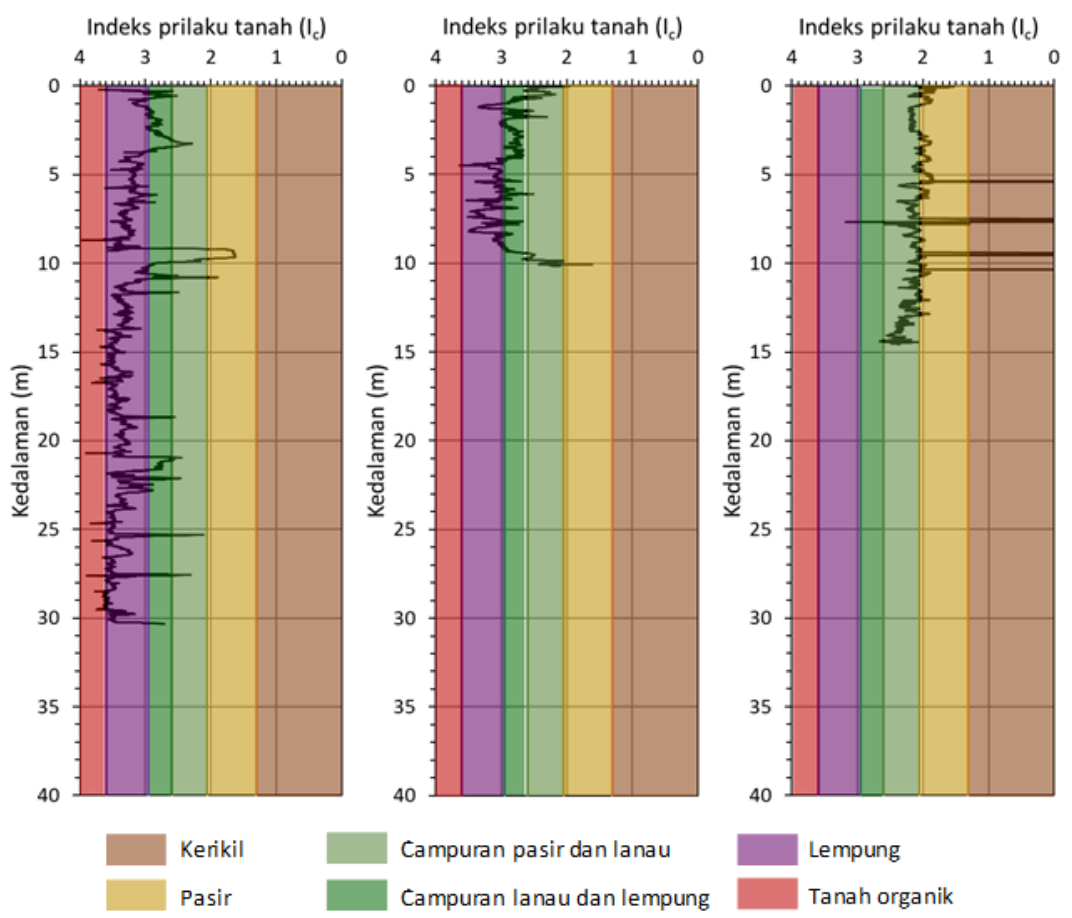

Gambar 4. Profil klasifikasi jenis lapisan tanah di lokasi CPTu-07 (kiri), CPTu-03 (tengah), dan CPTu-11 (kanan) berdasarkan nilai indeks perilaku tanah, Ic (Robertson, 1990). 

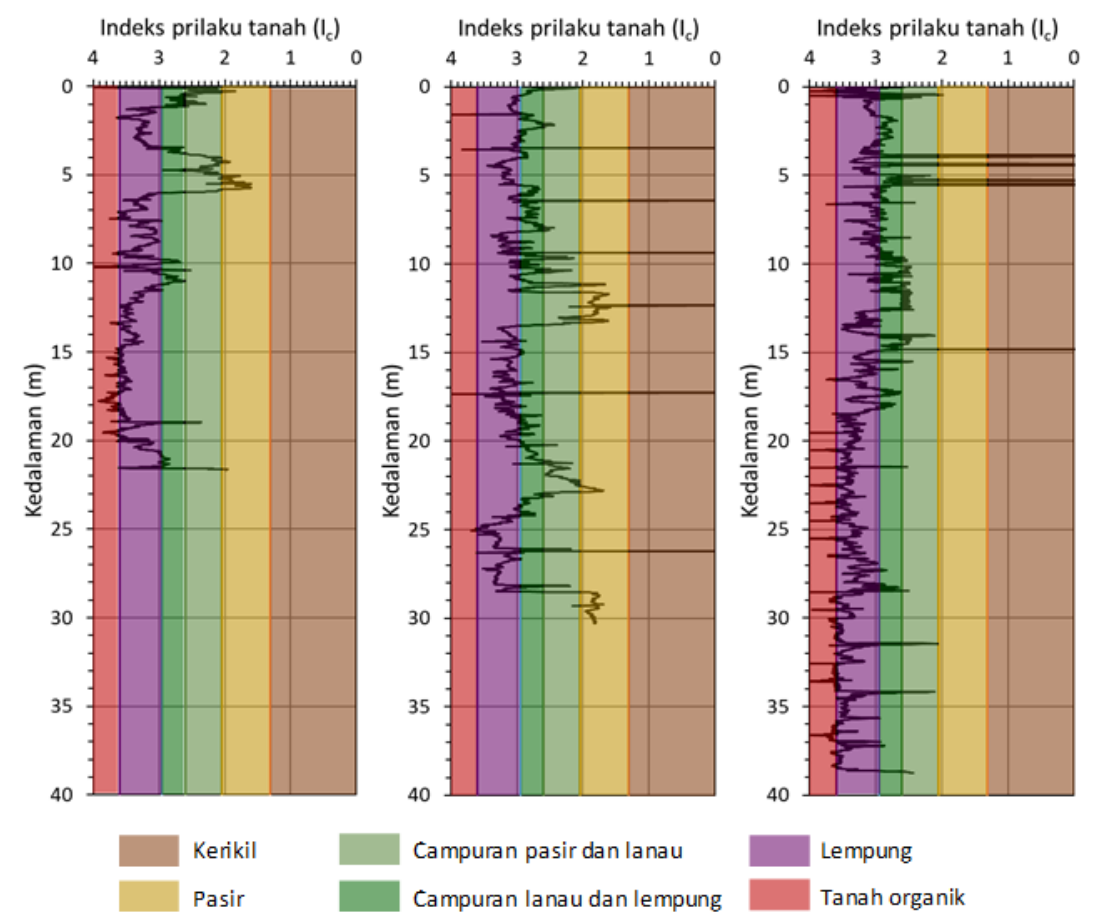

Gambar 5. Profil klasifikasi jenis lapisan tanah di lokasi CPTu-14 (kiri), CPTu-15 (tengah), dan CPTu-19 (kanan) berdasarkan nilai indeks perilaku tanah, Ic (Robertson, 1990).

\section{Percepatan Tanah Puncak (PGA)}

Tabel 2 menyajikan hasil perhitungan percepatan tanah puncak untuk sumber gempa bumi di Sesar Lembang (Mw 6,5) dengan menggunakan persamaan Boore et al. (1997) dan gempa bumi untuk sumber gempa megathrust $(\mathrm{Mw} 7,0)$ di zona persamaan Youngs et al. (1997). Berdasarkan Tabel 2, nilai percepatan tanah puncak sumber gempa Sesar Lembang lebih besar dibandingkan nilai percepatan tanah puncak sumber gempa zona subduksi. Perbedaan nilai percepatan tanah puncak ini disebabkan oleh jarak lokasi studi yang lebih dekat dengan sumber gempa Sesar Lembang

Tabel 2. Nilai percepatan tanah puncak ( $P G A)$ untuk setiap lokasi studi

\begin{tabular}{|c|c|c|}
\hline \multirow[b]{2}{*}{ Kode lokasi } & \multicolumn{2}{|c|}{ Percepatan tanah puncak $P G A(\mathrm{~g})$} \\
\hline & $\begin{array}{l}\text { Sesar Lembang } \\
\quad(\mathrm{Mw} 6,5)\end{array}$ & $\begin{array}{l}\text { Megathrust zona subduksi } \\
\text { Selatan Jawa (Mw 7,0) }\end{array}$ \\
\hline CPTu-02 & 0,206 & 0,080 \\
\hline CPTu-03 & 0,199 & 0,077 \\
\hline CPTu-04 & 0,191 & 0,080 \\
\hline CPTu-05 & 0,238 & 0,078 \\
\hline CPTu-07 & 0,233 & 0,080 \\
\hline CPTu-11 & 0,229 & 0,075 \\
\hline CPTu-14 & 0,206 & 0,083 \\
\hline CPTu-15 & 0,224 & 0,080 \\
\hline CPTu-19 & 0,217 & 0,078 \\
\hline
\end{tabular}

subduksi selatan Jawa dengan menggunakan dibandingkan sumber gempa zona subduksi. 
Sehingga berdasarkan nilai percepatan tanah puncaknya, maka potensi likuifaksi di setiap lokasi CPT akibat gempa bumi Sesar Lembang akan lebih tinggi dibandingkan potensi likuifaksi akibat gempa bumi megathrust dari zona subduksi selatan Jawa. Namun demikian, zona megathrust dapat menghasilkan gempa bumi dengan magnitudo $\mathrm{Mw}>7,0$, maka nilai percepatan tanah puncak (PGA) di wilayah Kabupaten Bandung menjadi lebih besar dari nilai PGA yang digunakan dalam penelitian ini sehingga akan menyebabkan potensi likuifaksi lebih besar dibandingkan dengan sumber gempa bumi Sesar Lembang.

\section{Analisis Potensi Likuifaksi}

Gambar 6 hingga Gambar 14 menyajikan hasil analisis potensi likuifaksi pada setiap titik lokasi studi berdasarkan data uji penetrasi konus. Berdasarkan grafik-grafik tersebut, likuifaksi terjadi pada kedalaman yang bervariasi. Hal ini disebabkan oleh perbedaan nilai $q_{c}$ dan $f_{s}$ yang mempengaruhi jenis tanah pada setiap kedalaman. Pada umumnya, likuifaksi terjadi apabila nilai tahanan konus, $q_{c}$ pada suatu kedalaman memiliki nilai yang kurang dari $15 \mathrm{MPa}$. Sedangkan nilai hambatan selimut, $f_{s}$ yang mengindikasikan suatu lapisan tanah berpotensi likuifaksi umumnya kurang dari $150 \mathrm{kPa}$.

Hasil perhitungan faktor keamanan berdasarkan sumber gempa Sesar Lembang (FK menghasilkan nilai yang lebih besar dibandingkan hasil perhitungan faktor keamanan berdasarkan sumber gempa bumi di zona subduksi $\left(\mathrm{FK}_{\mathrm{ZS}}\right)$, hal ini disebabkan karena nilai percepatan tanah puncak sumber gempa bumi Sesar Lembang lebih tinggi dibandingkan nilai percepatan tanah puncak sumber gempa bumi zona subduksi. Perbedaan nilai percepatan tanah puncak akan menyebabkan perbedaan nilai $C S R$ yang dihasilkan. Semakin besar nilai percepatan tanah puncak pada suatu titik lokasi, maka semakin besar pula nilai $C S R$ yang dihasilkan.

Berdasarkan hasil perhitungan CSR, dihasilkan nilai $C S R$ untuk sumber gempa Sesar Lembang lebih besar dibandingkan sumber gempa zona subduksi. Sehingga gempa yang terjadi pada Sesar Lembang memiliki potensi likuifaksi yang lebih tinggi dibandingkan gempa bumi yang terjadi pada zona subduksi selatan Jawa. Berdasarkan hasil perhitungan faktor keamanan pada seluruh titik lokasi studi, likuifaksi terjadi pada seluruh lokasi dengan kedalaman yang bervariasi pada jenis tanah campuran pasir dan lanau dari permukaan hingga kedalaman $15 \mathrm{~m}$.
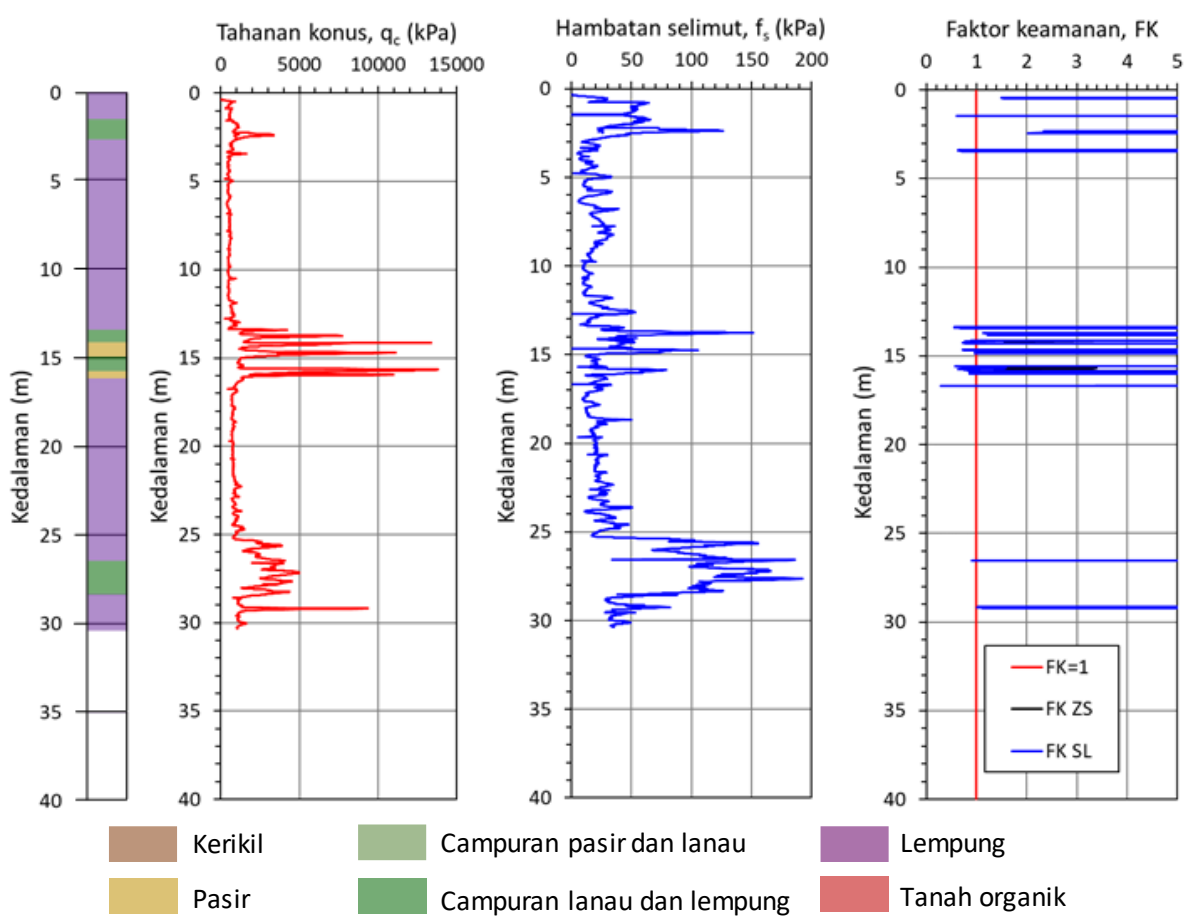

Gambar 6. Grafik profil jenis tanah, $q_{c}, f_{s}$ dan faktor keamanan terhadap likuifaksi (FK) berdasarkan data CPTu-02. 


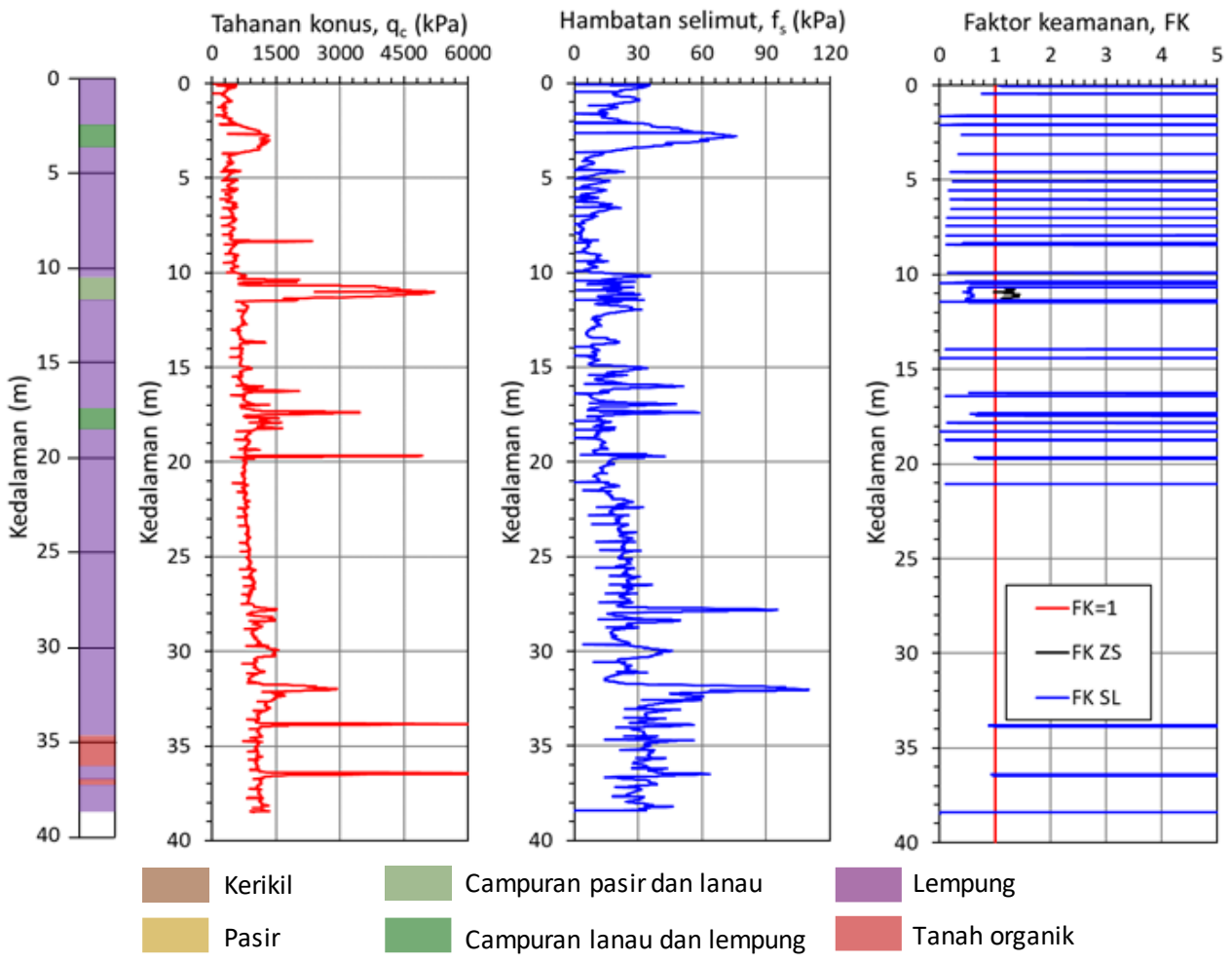

Gambar 7. Grafik profil jenis tanah, $q_{c}, f_{s}$ dan faktor keamanan terhadap likuifaksi (FK) berdasarkan data CPTu-03.

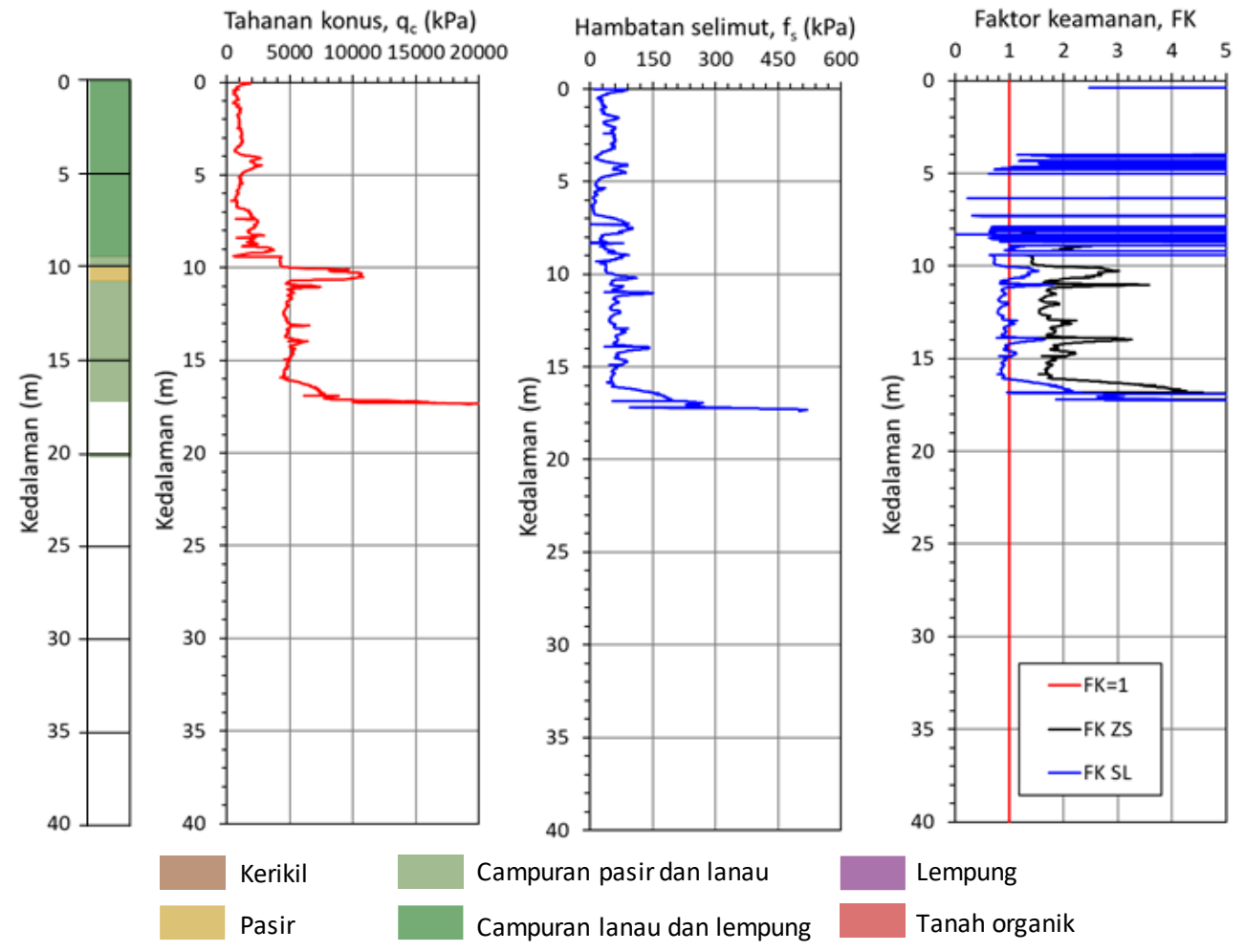

Gambar 8. Grafik profil jenis tanah, $q_{c}, f_{s}$ dan faktor keamanan terhadap likuifaksi (FK) berdasarkan data CPTu-04. 


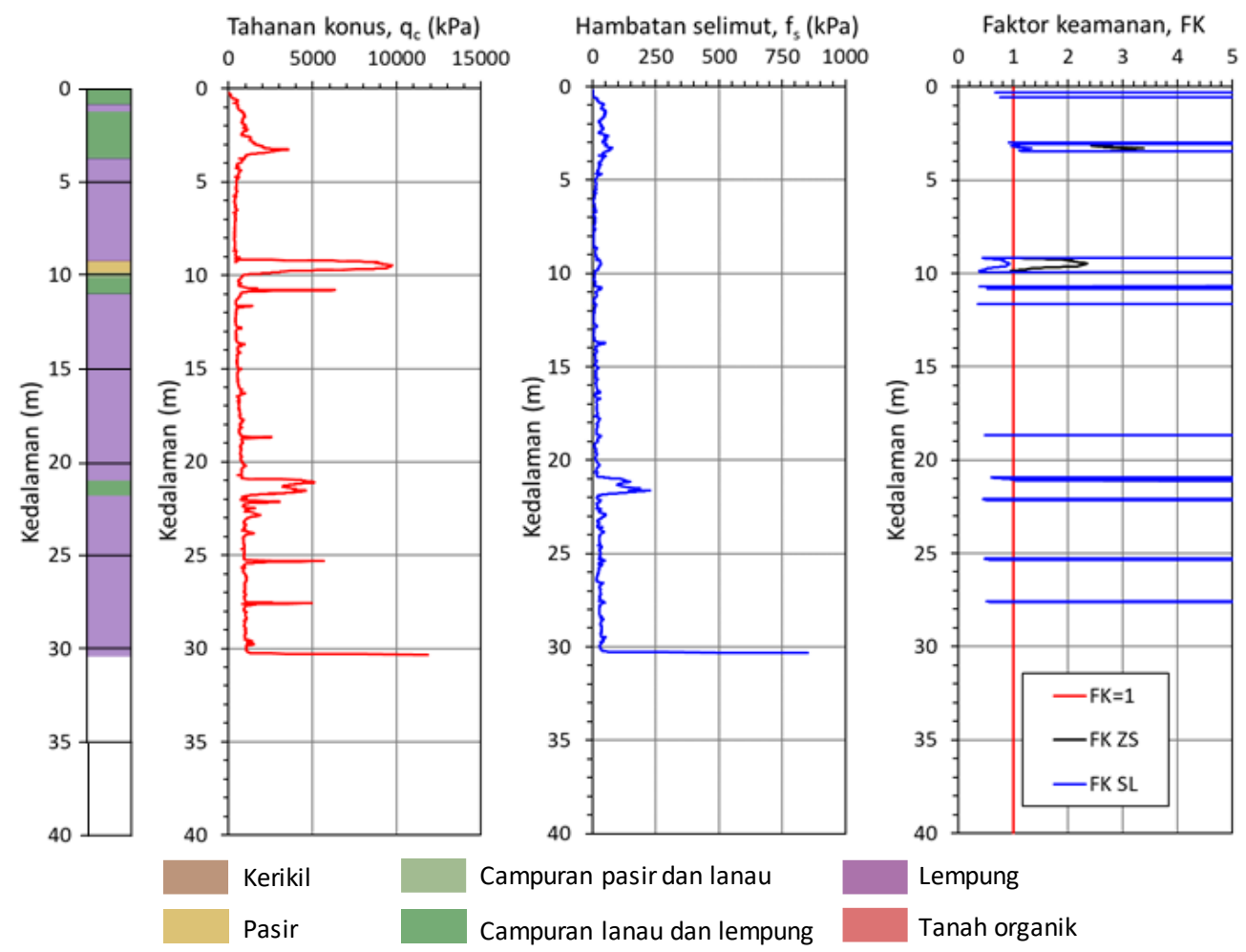

Gambar 9. Grafik profil jenis tanah, $q_{c}, f_{s}$ dan faktor keamanan terhadap likuifaksi (FK) berdasarkan data CPTu- 05 .

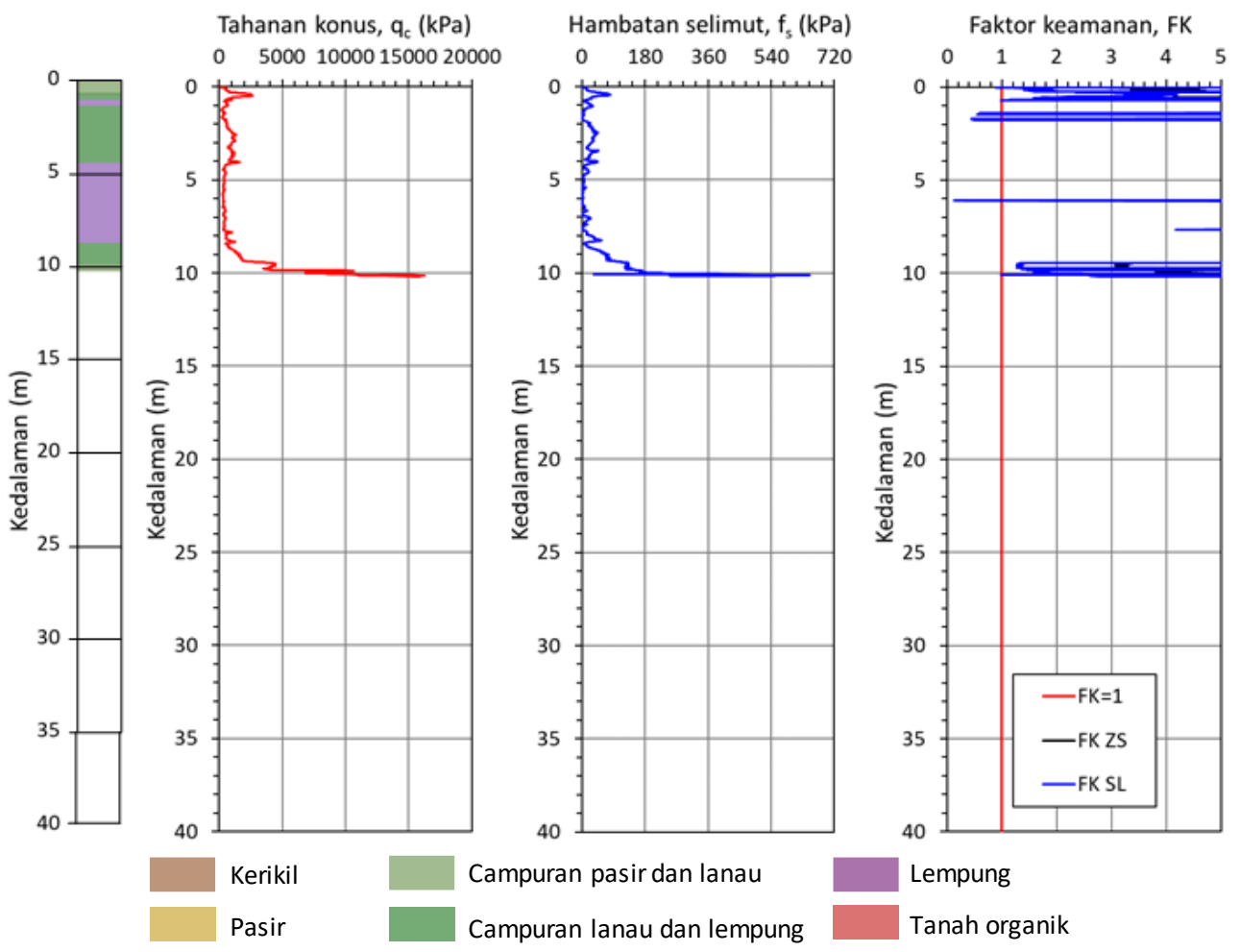

Gambar 10. Grafik profil jenis tanah, $q_{c}, f_{s}$ dan faktor keamanan terhadap likuifaksi (FK) berdasarkan data $\mathrm{CPTu}-07$. 


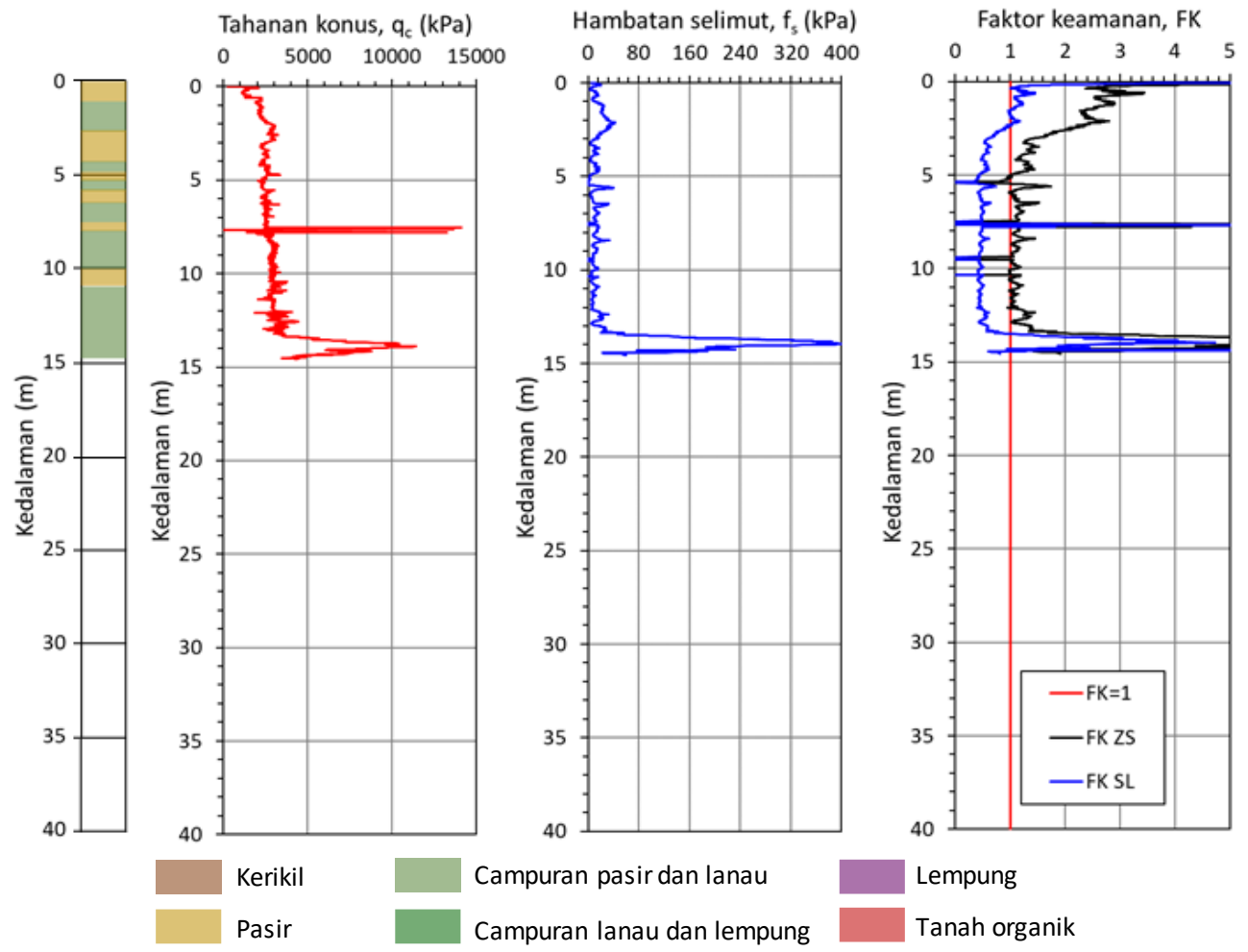

Gambar 11. Grafik profil jenis tanah, $q_{c}, f_{s}$ dan faktor keamanan terhadap likuifaksi (FK) berdasarkan data CPTu-11.

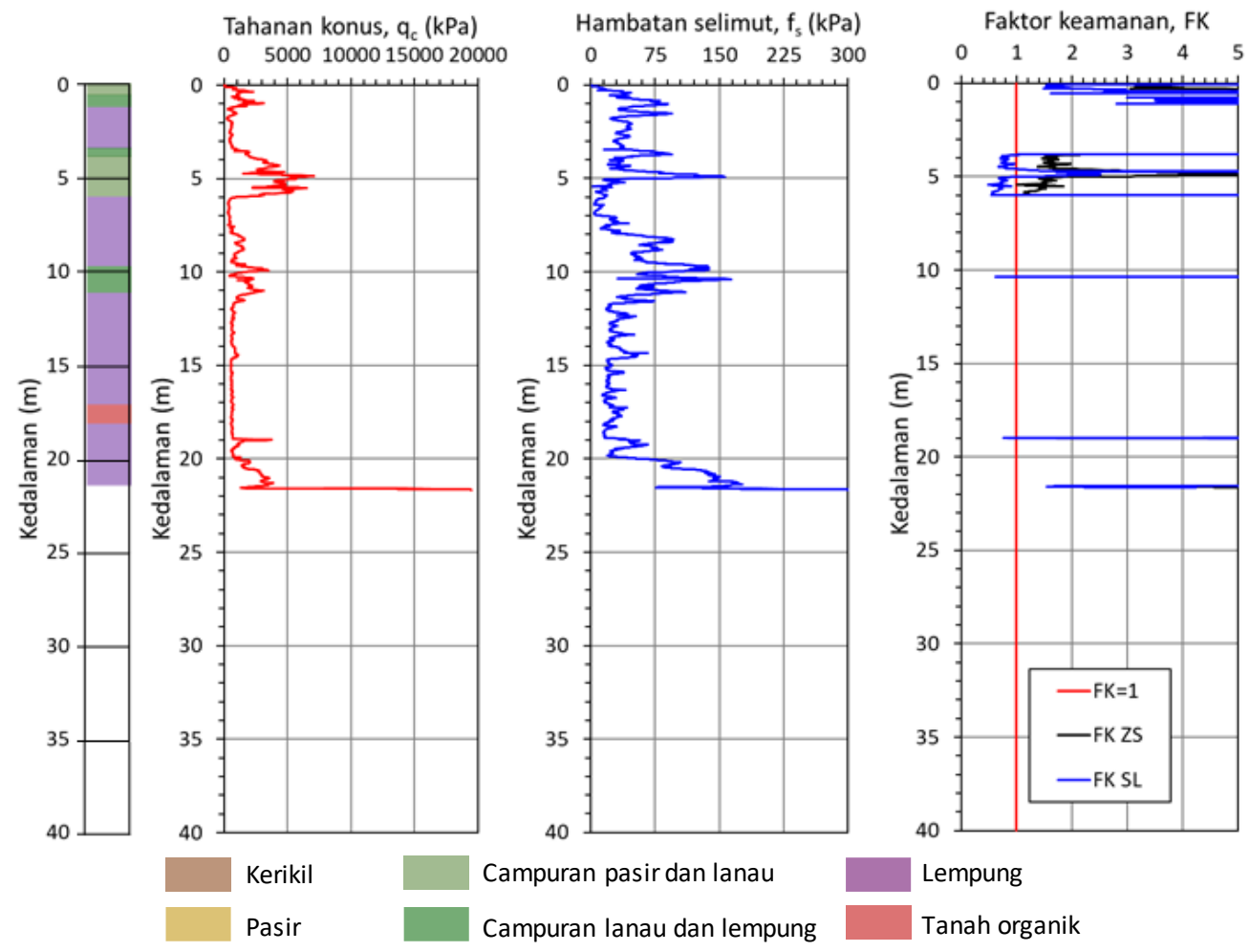

Gambar 12. Grafik profil jenis tanah, $q_{c}, f_{s}$ dan faktor keamanan terhadap likuifaksi (FK) berdasarkan data CPTu-14. 


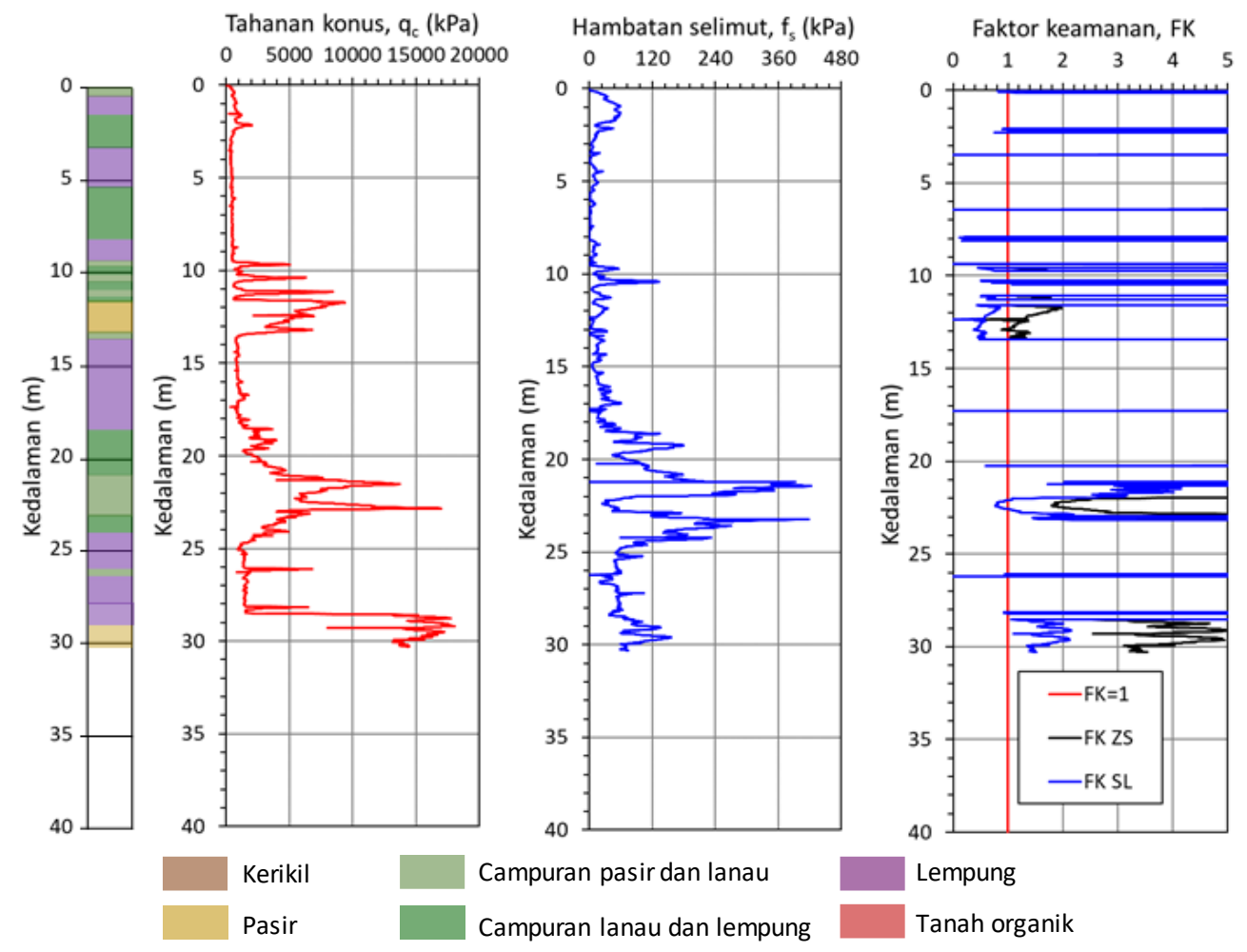

Gambar 13. Grafik profil jenis tanah, $q_{c}, f_{s}$ dan faktor keamanan terhadap likuifaksi (FK) berdasarkan data $\mathrm{CPTu}-15$.

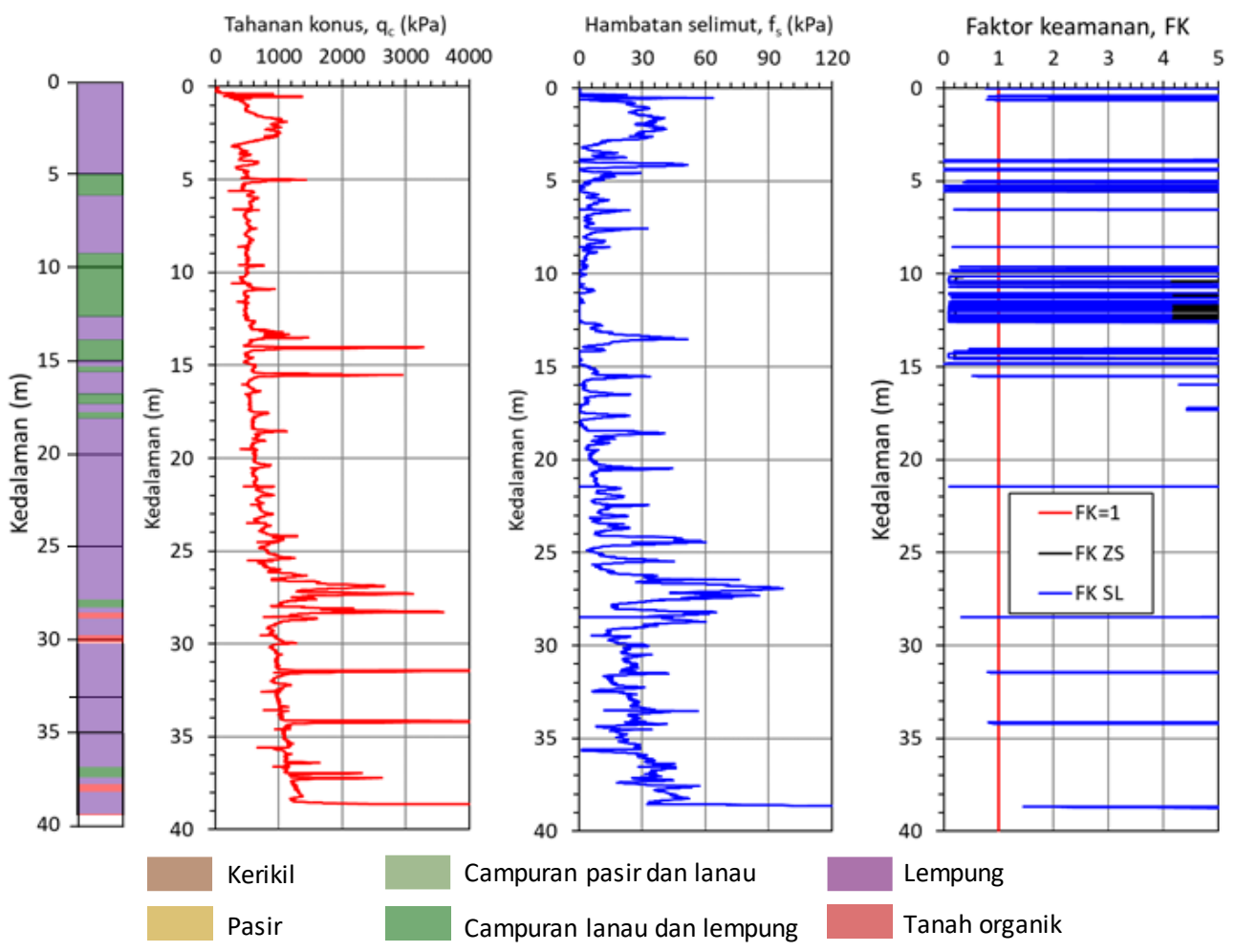

Gambar 14. Grafik profil jenis tanah, $q_{c}, f_{s}$ dan faktor keamanan terhadap likuifaksi (FK) berdasarkan data CPTu-19. 


\section{KESIMPULAN}

Hasil analisis potensi likuifaksi dengan menggunakan data Cone Penetration Test (CPT), memberikan informasi jenis lapisan tanah di wilayah Cekungan Bandung yang didominasi oleh tanah lempung dengan sisipan pasir lanauan sehingga likuifaksi terjadi pada lapisan campuran pasir dan lanau pada kedalaman yang sangat bervariasi yang umumnya mulai terjadi dari permukaan hingga kedalaman $15 \mathrm{~m}$. Untuk skenario magnitude gempa yang digunakan, besar penurunan tanah total mencapai $21 \mathrm{~cm}$ berdasarkan skenario sumber gempa megathrust (Mw 7,0) pada zona subduksi di selatan Jawa dan penurunan tanah total akibat gempa Sesar Lembang (Mw 6,5) mencapai 65,5 cm. Penurunan tanah yang bervariasi disebabkan oleh perbedaan ketebalan lapisan pasir lanauan di setiap lokasi dan percepatan tanah puncak yang dihasilkan oleh setiap sumber gempa bumi. Hasil studi ini merekomendasikan perlunya dilakukan analisis potensi likuifaksi di lokasi lainnya di seluruh wilayah Cekungan Bandung agar dapat disusun peta mikrozonasi kerentanan likuifaksi untuk menjadi pedoman dalam pengurangan risiko bencana likuifaksi.
Kontribusi masing-masing penulis: IW mengolah data CPT dan menyiapkan draft makalah, SF mensupervisi penulisan draft makalah dan AT menyiapkan data CPT, mensupervisi pengolahan data dan memperbaiki draft makalah. Masing-masing penulis memberikan kontribusi yang sama dalam penulisan makalah ini.

\section{UCAPAN TERIMA KASIH}

Penulis mengucapkan terima kasih kepada Kepala Pusat Penelitian Geoteknologi LIPI Bandung yang telah memberikan kesempatan kepada penulis untuk melakukan penelitian ini. Ucapan terima kasih juga disampaikan kepada para teknisi Laboratorium Geologi Teknik Pusat Penelitian Geoteknologi LIPI Bandung yang membantu selama melaksanakan penelitian ini.
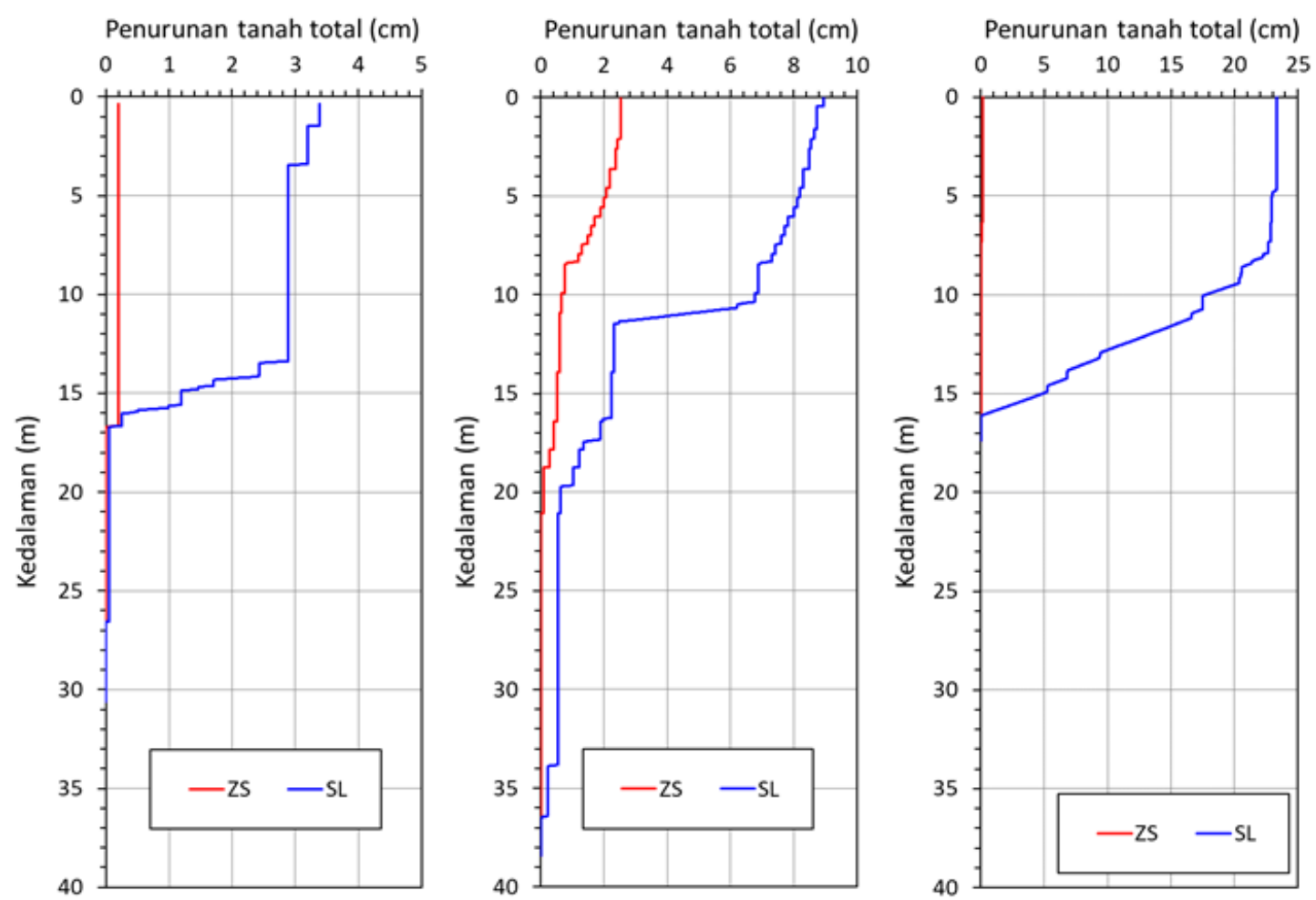

Gambar 15. Grafik penurunan tanah total akibat likuifaksi berdasarkan data CPTu-02 (kiri), CPTu-03 (tengah) dan CPTu-04 (kanan). 

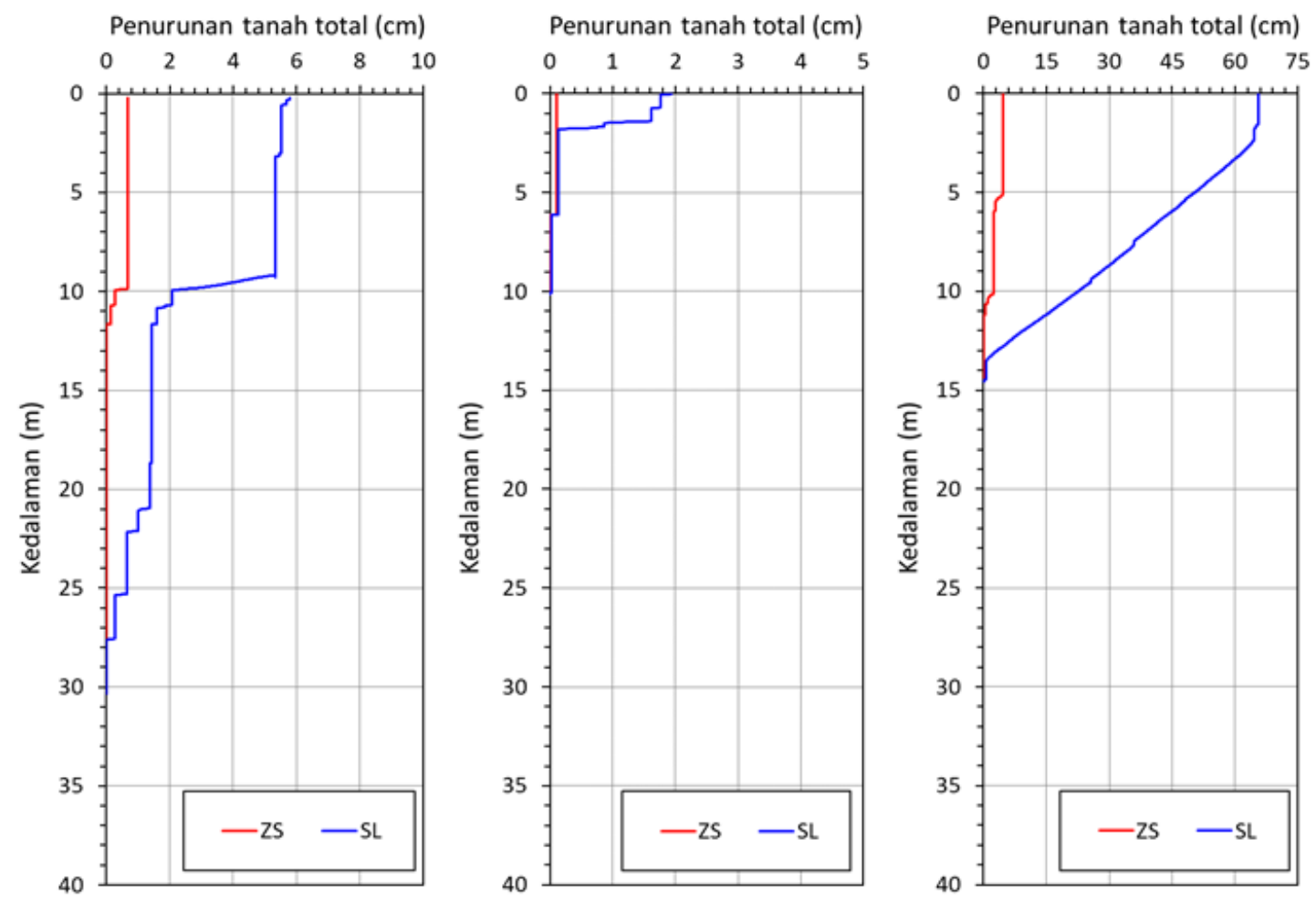

Gambar 16. Grafik penurunan tanah total akibat likuifaksi berdasarkan data CPTu-05 (kiri), CPTu-07 (tengah) dan CPTu-11 (kanan).
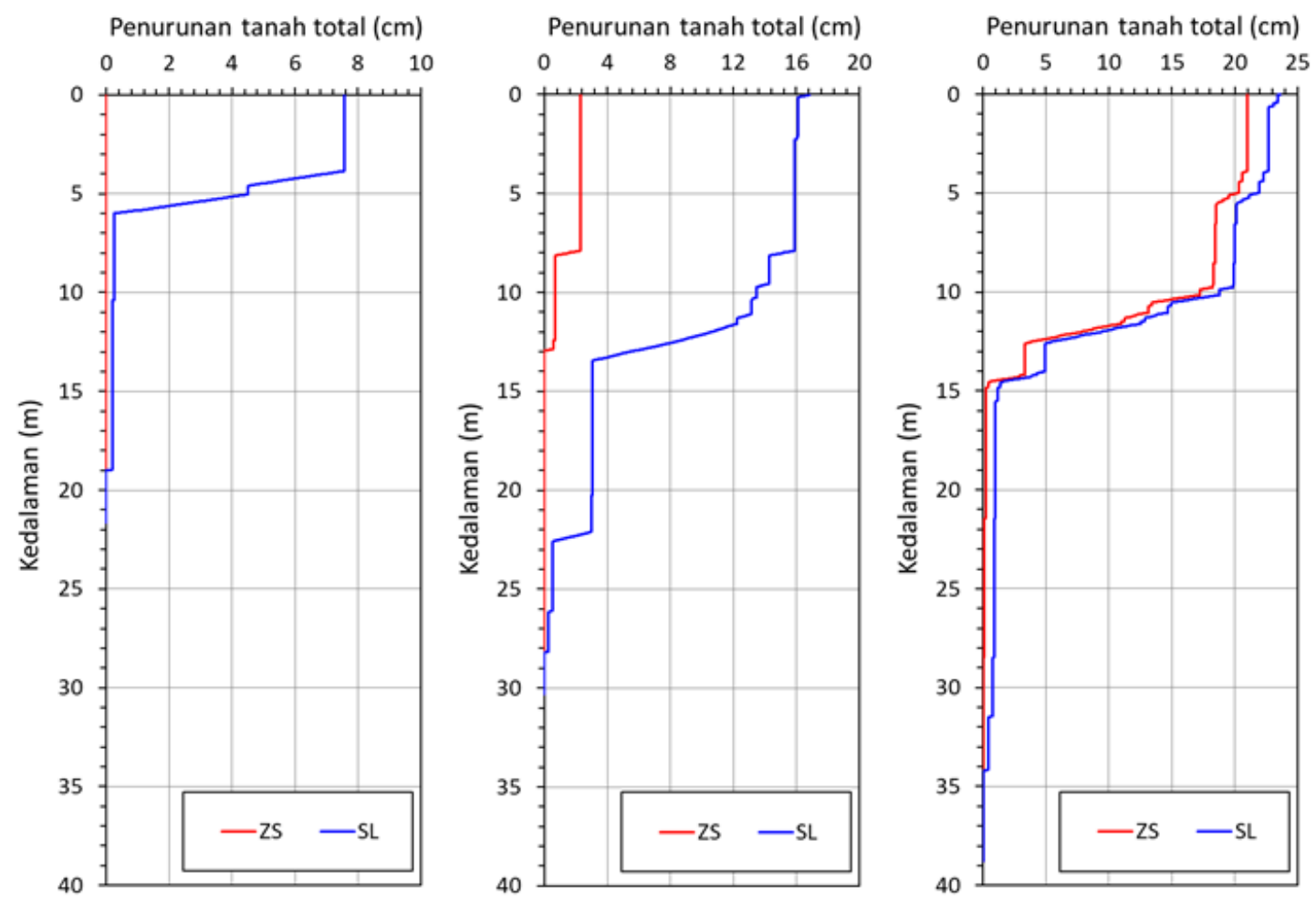

Gambar 17. Grafik penurunan tanah total akibat likuifaksi berdasarkan data CPTu-14 (kiri), CPTu-15 (tengah) dan CPTu-19 (kanan). 


\section{DAFTAR PUSTAKA}

Afnimar, Yulianto, E., Rasmid, 2015. Geological and tectonic implication obtained from first seismic activity investigation around Lembang fault. Geoscience Letters, 2:4.

Boore, D.M., Joyner, W.B., Fumal, T. E., 1997. Equations for estimating horizontal response spectra and peak acceleration from western North America earthquakes: A Summary of recent work. Seismological Research Letters, 128-153.

Bronto, S., Hartono, U., 2006. Potensi sumber daya geologi di daerah Cekungan Bandung dan sekitarnya. Jurnal Geologi Indonesia 1(1), 9-18.

Dam, M.A.C., Suparan, P., Nossin, J.J., Voskuil R.P.G.A., 1996. A chronology for geomorphological developments in the greater Bandung area, West-Java, Indonesia. Journal of Southeast Asian Earth Sciences, 14(1-2), 101-115.

Daryono, M.R., Natawidjaja, H.D., Sapiie, B., Cummins, P., 2019. Earthquake geology of the Lembang Fault, West Java, Indonesia. Tectonophysics, 751, 180191.

Harnandi, D., Iskandar, N., Nuzulliyantoro, A.T., 2000. Pengelolaan air tanah Cekungan Bandung. Buletin Geologi Tata Lingkungan, 1-6.

Hidayat, E., Brahmantyo, B., Yulianto, E., 2008. Analisis Endapan Sagpond pada Sesar Lembang. Geoaplika, 3(3), 151-161.

Hutasoit, L.M., 2009. Kondisi permukaan air tanah dengan dan tanpa peresapan buatan di daerah Bandung: hasil simulasi numerik. Jurnal Geologi Indonesia, 4(3), 177-188.

Ishihara, K., Yoshimine, M., 1992. Evaluation of settlements in sand deposits following liquefaction during earthquakes. Soils and Foundations, 32(1), 173-188.

Koesoemadinata, R.P., Hartono, D., 1981. Stratigrafi dan sedimentasi daerah Bandung. Prosiding PIT X Ikatan Ahli Geologi Indonesia, Bandung, 318-336.
Liao, S.S.C., Whitman, R.V., 1986b. Catalog of a liquefaction and non-liquefaction occurrences during earthquakes. Research Report, Department of Civil Engineering, M.I.T., Cambridge, MA.

Robertson, P.K., 1990. Soil classification using the cone penetration test. Canadian Geotechnical Journal, 27(1), 151-158.

Robertson, P.K., Wride, C.E., 1997. Cyclic liquefaction and its evaluation based on SPT and CPT: Summary Report. Proceedings of NCEER Workshop on Evaluation of Liquefaction Resistance of Soils, 40 pp.

Robertson, P.K., Wride, C.E., 1998. Evaluating cyclic liquefaction potential using the cone penetration test. Canadian Geotechnical Journal, 35(3), 442-459.

Seed, H.B., Idriss, I.M., 1971. Simplified procedure for evaluation of soil liquefaction potential. Journal of Soil Mechanics and Foundation Division, ASCE, 97(SM9), 1249-1273.

Silitonga, P.H., 1973. Peta Geologi Lembar Bandung, Jawa Barat, Skala 1:100.000. Pusat Penelitian dan Pengembangan Geologi, Bandung.

Sulaeman, C., Hidayati, S., 2011. Gempa bumi Bandung 22 Juli 2011. Jurnal Lingkungan dan Bencana Geologi, 2(3), 185-190.

Sudjatmiko, 2003. Peta Geologi Lembar Cianjur, Jawa Barat, Skala 1:100.000. Pusat Penelitian dan Pengembangan Geologi, Bandung.

Tjia, H.D., 1968. The Lembang Fault, West Java. Geologie En Mijnbouw, 47(2), 126-130.

Tohari, A., Sugianti, K., Soebowo, E., 2011. Liquefaction potential at Padang City: a comparison of predicted and observed liquefaction during the 2009 Padang earthquake. Jurnal Riset Geologi dan Pertambangan, 21(1), 7-18.

Tohari, A., Sugianti, K., Syahbana, A.J., Soebowo, E., 2015. Kerentanan likuifaksi Kota Banda Aceh berdasarkan metode uji penetrasi konus. Jurnal Riset 
Geologi dan Pertambangan, 25(2), 99110 .

Towhata, I. 2008. Geotechnical Earthquake Engineering, publ. Springer, 522 pp.

USGS, 2009. M 7.0 - Java, Indonesia. United States of Geological Survey, https://earthquake.usgs.gov/earthquakes /eventpage/usp000h152/executive. Diunduh pada tanggal 9 Mei 2019.

Van Bemmelen, R., 1949. The geology of Indonesia. Government Printing Office, The Hague, Netherlands, 732 pp.

Youd, L.T., Tinsley, J. C., Perkins, D. M., King, E. J., Preston, R. F., 1979. Liquefaction potential map of San Francisco, California, in progress on Seismic Zonation in the San Francisco Bay Region, USGS Circular, 807.

Youd, T. L., Idriss, I. M., Andrus, R. D., 2001. Liquefaction resistance of soils. Summary Report from the 1996 NCEER and 1998 NCEER/NSF Workshops on Evaluation of Liquefaction Resistance of Soils. Journal of Geotechnical and Geoenvironmental Engineering, 127(10), 817-833.

Youngs, R. R., Chiou, S. J., Silva, W. J., Humphrey, J.R., 1997. Strong ground motion attenuation relationships for subduction zone earthquakes. Seismological Research Letters, 68, 5873. 
Ambarwati et al.: Analisis Potensi Likuifaksi di Cekungan Bandung dengan Menggunakan Metode Uji Penetrasi Konus 